\title{
E. Maud Graham, edited by Michael Dawson, Catherine Gidney, and Susanne M. Klausen A Canadian Girl in South Africa: A Teacher's Experiences in the South African War, 1899-1902
}

Edmonton: University of Alberta Press, 2015. 292 pp.

\section{Benjamin Bryce}

University of Northern British Columbia

Maud Graham's 1905 book about her experiences in South Africa (1902-04) offers a fascinating perspective on the country at the tail end of war and in the two years after peace between Boer farmers and the British Empire. The book's title is deceptive, because it recounts her experiences starting only at the end of the South African war, and she offers no commentary on events or experiences from 1899 to 1901. Historians Michael Dawson, Catherine Gidney, and Susanne M. Klausen have made this primary document accessible by republishing it, adding footnotes to Graham's text to help contemporary readers, and writing an extensive fifty-page introductory analysis of her account. They have included many of the wonderful photographs that appeared in Graham's original publication and have added more from Graham's private collection and relevant archives.

At the age of twenty-six, Maud Graham was one of forty Canadian teachers and one of three hundred British subjects who travelled to South Africa to teach Boer children, with the goal of "remaking South Africa in Britain's image" (xii). The editors write that this imperial undertaking was "explicitly designed to maintain and enhance Britain's hegemony in Southern Africa" (xvi). Graham was a "colonial contributor to imperial endeavours" (xv-xvi), and she spoke critically of the efforts of leaders of the Dutch Reformed Church in South Africa to ensure that Boer children continued to learn Dutch after the British victory in the South African war. Graham shares her experiences in Norval's Pont concentration camp in the Cape Colony and in Fauresmith and Kroonstad in the Orange River Colony after hostilities ceased in 1902. Her positive take on camp life and the reasons for Boer internment offer an 
example of how everyday actors supported British imperialism and how the voice of one woman could help Anglo-Canadians remain oblivious to colonialism and enthusiastic about the evolving British world in the decade before the First World War.

Although the editors do not raise this point, it seems important to reflect on Graham's main audience. Her book was based on newspaper articles she had previously published in the Montreal Daily Witness. Her comparisons of the South African veldt with the Canadian prairies, or her interest in the few Canadians she met during her two years abroad, seem to be statements made with her audience in mind. She took a nostalgic interest in the accent of a Canadian soldier she met who represented "six feet of well-developed young Canada" (112). Graham's discussions of Canada or its place in the British Empire are presented to a specific audience, either the readers of a Montreal newspaper or the largely Canadian buyers of a book. As a public record rather than a diary, this question of audience has created some noteworthy lacunae in her account. She does not speak about homesickness, illness, or romance. Even her support of the British imperial project and her lack of criticism of the conditions in camps and the suffering in the year after the war may have filtered her own perspectives into a vision of South Africa that she or her editors wanted Canadian readers to receive.

The editors' introduction does a splendid job of framing Graham's book by providing the necessary background information on the Second Anglo-Boer War, the history of Canadian teachers travelling to South Africa in 1902, and a brief biography of Graham before and after her two years there. Graham's account will help others understand how the British and English-speaking Canadians in South Africa perceived Boers and native southern Africans at the turn of the twentieth century, and her descriptions reveal details about everyday life in South Africa at an important moment of transition.

The editors state that Graham's account "provides an entry point into discussions about imperialism, emergent English-Canadian nationalism, New Women, schooling, issues of racism, and whiteness" (xlv). Throughout the text, Graham makes sporadic statements about her support of the British imperial project, the co-existence of Canadian and British identities, and female professionals. Her account also reveals some of the dynamics of race relations between the British and various native southern African groups, as well as instances where the British and Boers were united in using race to maintain hierarchies of power. Considering the journal where this review appears, it is worth mentioning that education plays only a small role in this book. Although Graham worked as a teacher throughout her time in South Africa, only one of fifteen chapters (eight pages in length) is dedicated to education. She devotes far more attention to her travel to and from South Africa, her experiences in the United Kingdom, her impressions of South Africa outside of work hours, and the poverty that many Boers experienced during and after the war. Graham's book represents the perspective of a well-embedded outsider reporting to far-removed readers, rather than that of a female teacher involved in international or imperial education.

This republication makes Graham's rich primary source more accessible to students and researchers of the British world and South African history who lack access 
to North American libraries - according to Worldcat.org, only six copies of the original book exist in libraries outside Canada and the United States. Dawson, Gidney, and Klausen's work provides scholars of the British world and South Africa the turn of the twentieth century with an accessible primary account that can be used for both teaching and research. Their well-researched introduction and analysis of Graham's book will be of interest to a wide range of scholars who study in imperialism, dominion-imperial relations, and travel writing. 